\title{
Megasporogenesis and the development of the embryo sac in Melica uniflora Retz.
}

St. KRUPKO

\section{INTRODUCTION}

Throughout the XIXth century and for a part of the XXth there existed a conviction among embryologists that grasses have an unusually uniform embryology. This concerned not only the embryo but also the embryo sac. It was believed that for the whole family the Polygonum type of embryo sac was generally valid and it was forgotten to note the elementary statistical relation of the number of species embryologically studied to the total number of species known in this family. This relation is more or less as follows. If we can believe the calculations of Stover (1937) in only 47 species investigators have reported the developmental type of embryo sac, even though the embryology of 63 species has been studied. On the other hand the number of species in the grass family Willis (1951, 14-page 299) believes to be around 4500 , and presently there are certainly more. Thus the embryological studies refer to a very minute proportion of species and even in these certain variations on the Polygonum type are observable. This belief in the uniformity of the embryo sac type directed critical approach to the already published exceptions. The earliest known exception was the bisporial embryo sac of the Allium type described by A. Fischer (1880) already in 1880 on Melica nutans and M. altissima. The fact that from the studies of Fischer already 80 years have passed is an encouragement to take up studies in this direction in order to check his results. Already Stover (1937) and S. C. Maheshwari (1955) have called for the need of such studies. This has encouraged the author of the present paper to take up studies on the development of Melica uniflora. This was also the motive behind the masters thesis of A. Walczak (1965), who studied again the species Melica nutans, described by Fischer. She has confirmed the results of Fischer entirely in all details. However two reservations have to be introduced into these introductory considerations. The first one concerns the bisporial type of embryo sac with 8 nuclei. Presently, as is reported by Johri (1963) in his chapter "Female gametophyte", page 77 (Recent Advances in the Embryology of the Angiosperms, ed. P. Maheshwari, 1963) it is common to distinguish between the Allium type, where the bisporial embryo sac develops from the chalazal binucleate cell of the diad and the Endymion - (Battaglia 1958) type, earlier referred to as Scilla type (based mainly on the study of Scilla hispanica, the synonym of Endymion), in which the bisporial embryo sac develops always from 
the micropylar, binucleate diad. In the Endymion type chalazal diad remains beside the functional embryo sac for a long time and often even develops 4 nuclei. Often various authors refer to it as "antigone" (S. C. Maheshwari 1955). Stover in his paper, referred to above, when listing grasses with a different type of embryo sac than Polygonum, reports that Schnarf (1926) has described a bisporial Scilla type in the grass Coleanthus subtilis. However Schnarf writes very clearly on page 107 that even though the micropylar megaspore can at times be binucleate, it is the one that degenerates and the embryo sac develops only from the lower megaspore which is uninucleate and therefore it is of the Polygonum type. Thus in Stover's listing the only remaining exceptions from the Polygonum type are Melica nutans and $M$. altissima which according to Fischer have embryo sac of the Allium type and Cornucopia nocturnum by Guignard (Schnarf 1926), the name of which it is not possible to find in the Index Kewensis, and therefore it is not possible to investigate the species again.

The second reservation concerns the time factor. Since the publication of Stover's list in 1937 almost 30 years have elapsed! Since that time not only new grass species were reported as having a Polygonum type of embryo sac development, but also some were found to have an Adoxa type of tetrasporial embryo sac. e.g. Aly Mohamed, H. and Frank Gould (1966) in Boutelona curtipendula. Earlier still Brown and Emery (1958) have found in the apomictic tropical species of tribes Panicoideae and Andropooaneae the consistently regular occurrence of a tetra-nucleate embryo sacs.

Both the above mentioned reservations throw doubt on the belief that grasses are uniform in their embryology. Furthermore, these exceptions encourage research into other species and even to review some of those studied earlier.

Melica uniflora is a species characteristic for the plant association Melineto-Fagetum. Apart from that it also occurs in mixed forests with beech, and in the Poznań and Olsztyn voievodships it even extends beyond the range of beech occurrence. The newest atlas of distribution of european species (Me usel et al. 1965 claims on page 33 that its occurrence outside the range of beech it extends along the Baltic as far as the Niemen river.

\section{MATERIAL AND METHODS}

Spiklet of Melica uniflora have been collected and fixed by Dr M. Zenkteler in a beech-oak forest around Bytyń, near Poznań, in the year 1958 from the 5th to the 21st of April and in 1959 from the 28th of April to the 28th of May. B. Czosnowska, M. Sc., has been collecting them in the same locality in 1965 from the 3rd to the 9th of June. This material was fixed in two fixatives; in Navashin's fixative Stockholm's modification and in F.A.A. Then the material was impregnated with paraffin and cut into sections $8-15 \mu$ thick. Two staining methods were employed. Heidenhains hematoxiline counterstained with Fast Green in clove oil and Crystal Violet. 


\section{STUDIES CONDUCTED}

The first signs of differentiation in the internal structure of the nucellus of Melica uniflora are already observable when the ovule is in an orthotropous position and at its base only initials of the internal integument are visible. In the subepidermal layer or in the second one below the epidermis there develops a large archesporial cell (fig. 1). As usually in Gramineae, it does not cut off a parietal cell, but it directly becomes the megaspore mother cell. In the nucleus of this cell meiosis takes place and in the diakinesis stage (fig. 2) it is already possible to observe a substancial turn of the ovule (fig. 3). At this stage it is already in the campylotropous position.

Following the first meiotic division a diad is formed. Its further development can be twofold. In many diads the II meiotic division takes place only in the chalazal cell (fig. 4) which becomes binucleate. The micropylar cell of the diad remains uninucleate and begins to degenerate rather rapidly under pressure of the fast growing binucleate chalazal cell. From this chalazal cell develop as a result of further mitotic divisions an 8-nucleate embryo sac. As can be seen from the above description it is a bisporial, Allium type of embryo sac. It differs however from that described by Fischer (1880) and by A. Walczak (1965) in Melica nutans, since in the latter always both cells of the diad have two nuclei, even though the binucleate, micropylar cell always degenerates.

The second pathway of diad development in M. uniflora depends on the IInd meiotic division taking place in both cells of the diad. Thus two binucleate diad cells develop, of which the micropylar one soon degenerates. This type of development in Melica uniflora occurs just as commonly as the former, even though it is the only type in Melica nutans, as Fischer (1880) and A. Walczak (1965) have shown. We can see it in fig. 5 where the periclinal divisions of the nucelar epidermis have moved both the diads to the level of the third layer of cells under the epidermis. However both these paths of diad development represent the bisporial Allium type of embryo sac.

During the studies on Melica uniflora a few deviations from this type have been observed. Such an exception is presented in fig. 6. Here we can see a 4-nucleolate embryo sac, without the central vacuole, and with the four nuclei arranged in a cross, similarly as it takes place in the tetrasporial development of the Penaea type. leading to the 16-nucleate embryo sac. Stephens (1909). In this drawing we can see that the periclinal division of the epidermis has moved the sac to the level of the 5 th layer under the epidermis. There are no remains of squashed megaspores or diads. The cytoplasm in the sac is dense and there is no central vacuole, which is always present in the tetra-nucleate embryo sac. Thus it is reasonable to interpret this deviation from the dominant type as the early stage of a tetrasporial embryo sac of the Penaea type. Such a deviation was observed only twice and presumably it does not develop further since the later stages have not been seen.

The chalazal binucleate cell grows fast. Between its nuclei a vacuole develops, which separates these nuclei and drives them to the poles of the cell (fig. 7). Over the micropylar pole remains are still visible of the micropylar cell of the diad 

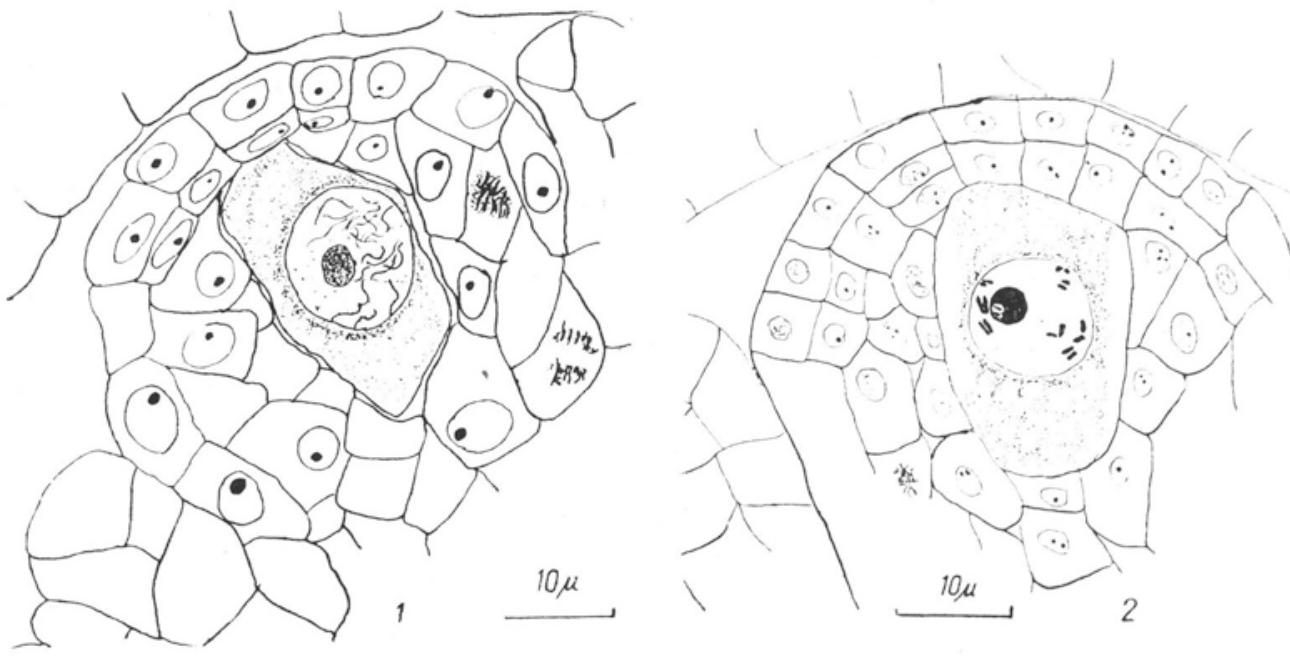

Fig. 1 and 2. Melica uniflora: fig. 1 - Megaspore mother cell $-10 \mu$; fig. 2 -Diakinesis in megaspore mother cell $-10 \mu$.

Sections stained with Hematoxiline., counterstained with Fast Green except for fig. 16 (Crystal Violet and Orange G), and fixed in F.A.A. except figs. 1, 5, 15 and 16 (Navashin).
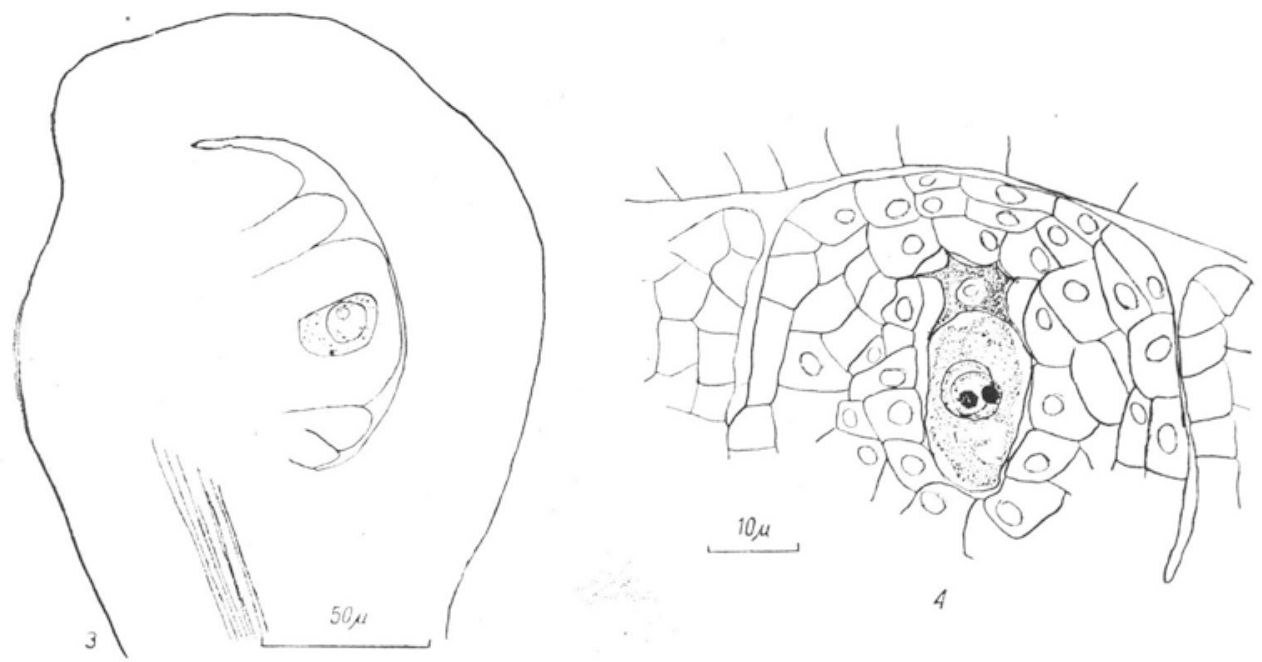

Figs 3 and 4: fig. 3. Drawing of an ovule during diakinesis $-10 \mu$; fig. 4-Diad $-10 \mu$. 

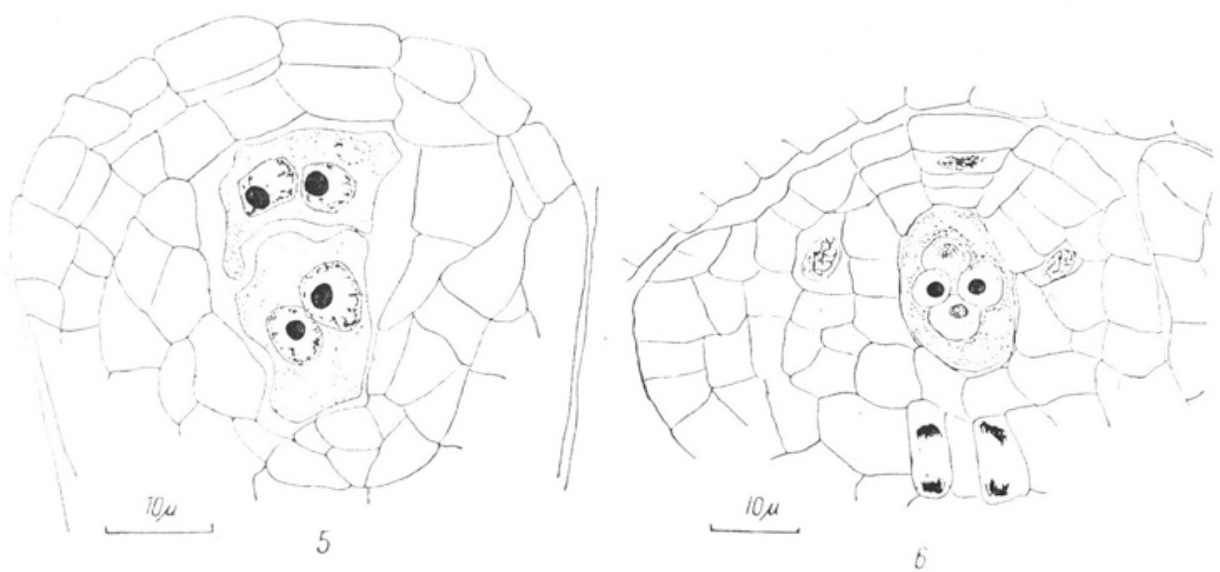

Figs 5 and 6: Fig. 5. Diad (a synthetic drawing) $-12 \mu$; fig. 6 - A tetrasporial embryo sac young stage (synth,.) $-10 \mu$.

and the crushed cells of the nucellus. Such a picture presents no problems in clas sifying it as a binucleate embryo sac.

The mitotic division that takes place soon after, leads to the development of the tetranucleate sac (fig. 8) with a characteristic arrangement of nuclei with 2 at each pole of the cell. In spite of the collosal growth of the embryo sac it is sometimes still possible to distinguish at its micropylar end, among the crushed cells of the nucellus also the crushed remains of the micropylar cell of the diad. Following the next mitotic division an embryo sac develops with 8 free nuclei. Such sacs with normally developed nuclei have been observed several times. Of special interest is a deviation in the differentiation of the nuclei at the micropylar end of the cell. It has been observed only once. Three of the nuclei were much smaller than the fourth, in the lower position, presumably the polar nucleus. These three were even smaller than the nuclei of the future antipodals (fig. 9).

At the 8-nucleate stage of the organised embryo sac (fig. 10) it is possible to observe hooked synergids with the typical arrangement and an egg cell with a large nucleus, much greater than those of the synergids. In its cytoplasm under the nucleus it is possible to see numerous vacuoles. Polar nuclei usually remain unfused until fertilization itself, however on our fig. 10 they are exceptionally early fused, forming a secondary nucleus of the embryo sac. The antipodals in this embryo sac (fig. 11) are beginning to degenerate. Indeed their degeneration begins as a rule very early in Melica uniflora. In this species are always only three antipodals.

It is worth noting here that there is a fast enlargement of the sac, particularly in the direction of the micropyle. This characteristic has been discussed in more details by Czosnowski (1965). In Melica uniflora the organised embryo sac reaches with its tip to the epidermis or to the layer just below it. In the 4-nucleate stage of the sac development it is embedded in the 5th layer under the epidermis or lower. 

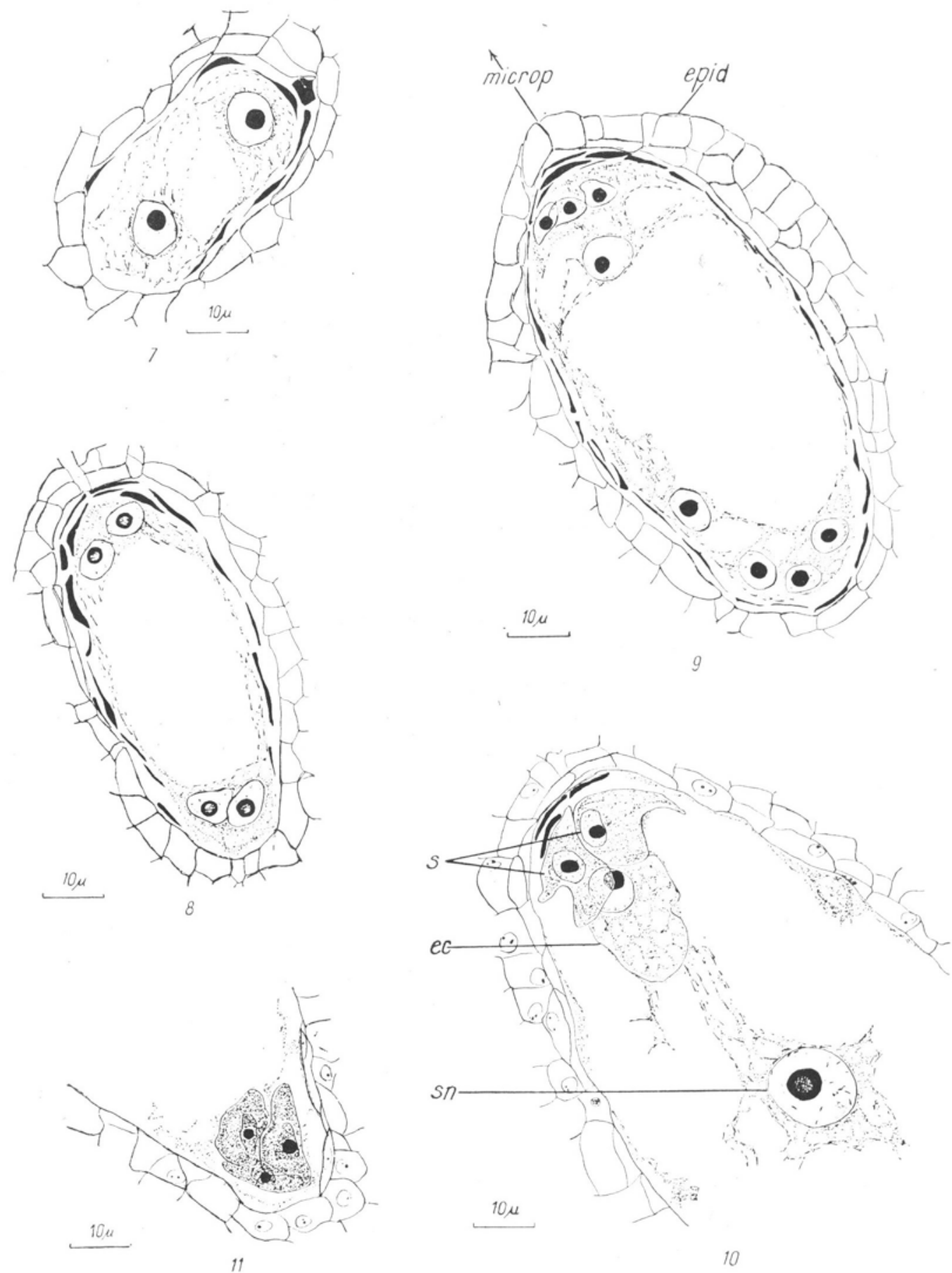

Figs. 7-11: fig. 7. A binucleate embryo sac (synth.) $-15 \mu$; fig. $8-$ A tetranucleate embryo sac (synth.) - $15 \mu$; fig. 9 - An 8-nucleate embryo sac (synth.) $-15 \mu$; fig. 10 - The egg apparatus and the secondary nucleus (synth.) $-12 \mathrm{u}$; fig. 11 - Anitipodals - continuation of the previous preparation (synth.) $-12 \mu$.

Abbreviations

$\begin{array}{lll}e c-\text { egg cell } & p n-\text { polar nucleus } & \text { epid }- \text { epidermis } \\ s-\text { synergid } & s n-\text { secondary nucleus } & \text { microp-micropyle }\end{array}$



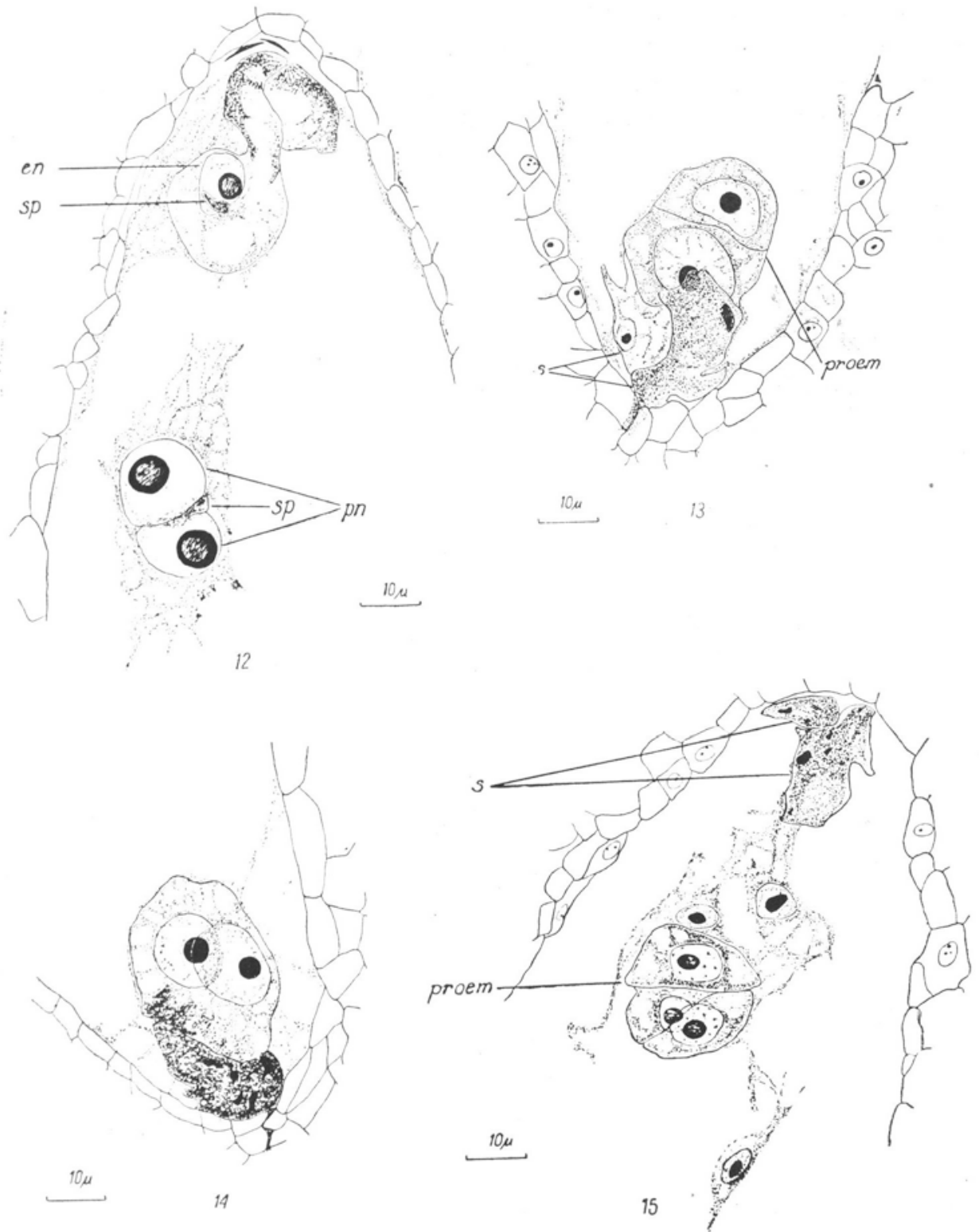

Figs. 12-15: fig. 12. Double fertilization (synth.) $-12 \mu$; fig. $13-$ Two celled proembryo (synth.) $-15 \mu$; fig. $14-$ Binucleate proembryo (synth.) $-15 \mu$; fig. $15-$ Tri-celled proembryo (synth. ) $-12 \mu$. 
Double fertilization takes place when the polar nuclei have not yet fused, even though they are tightly appressed to each other (fig. 12). In this figure it is possible to see the egg cell with a small male nucleus of an ill defined structure. Above the egg nucleus it is possible to see the remains of the pollen tube and the outline of one synergid. In the angle between the polar nuclei there is the second male nucleus.

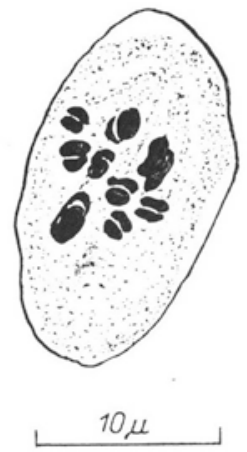

Fig. 16. Metaphase $I$ in pollen mother cell $-10 \mu$.

The antipodals in this embryo sac are already in degeneration. The egg cell following fertilization undergoes a period of rest. When the first division of the zygote takes place there usually is already at least 10 free nuclei of the endosperm. In fig. 13 it is possible to see a twocelled proembryo and near it a still well preserved synergid. The shape of the pollen tube remains are still visible in the region of the second degenerated synergid. At this stage there are already numerous nuclei of the endosperm.

Stage as in fig. 14 has been found only once. The degenerated antipodals and the presence of 10 nuclei of the endosperm in the cell seem to indicate that it is long after fertilization. This is also supported by the absence of synergids and presence of slight remains of one of their nuclei and of the vegetative tube nucleus. However it is difficult to interpret these two nuclei lying close to each other as a male nucleus and the egg cell nucleus, because in Melica uniflora the male nuclei are so very small. Even assuming the very common phenomenon of growth of the male nucleus, when it lies in contact with the nucleus of the egg cell we must expect to see the process of fusion between their content. However in fig. 14 both nuclei are of the same size, in the resting stage and without any signs of dissolution of the adjacent nuclear membranes. Assumption that division into two cells has already taken place and that the cell wall dividing them lies in the plane of the drawing would require the first division to be longitudinal. As is known it is very unusual in the flowering plants for the first zygotic division to be longitudinal. This would represent the Piperad group in the embryogenic classification, characteristic for $2-3$ primitive orders of the Dicotyledoneae, unknown as yet in the grasses.

The only remaining supposition is that it represents a binucleate proembryo, in which cytokinesis has exceptionally not developed.

A tri-celled proembryo has occurred in our materials only once (fig 15). The 
oblique division of the apical cell resulted from the section being cut obliquely. Besides the proembryo endosperm nuclei are visible. Further up remains of the completely degenerated synergids are visible.

The number of bivalents and pollen grain nuclei

Longitudinal sections of Melica uniflora flowers gave longitudinal sections of the ovule and at the same time sections of the anthers. Thus it was not difficult to find meiosis in the pollen mother cell. However the views of the I meiotic metaphase from the pole were in such sections rare compared with views from the equator. In spite of that several times it was possible find well positioned plates with view from the equator (fig. 16). On these it was easy to count the number of bivalents and to determine that $\mathrm{n}=9$. This is in full agreement with the diploid number of chromosomes for Melica uniflora given by Darlington and Wylie (1955).

In flowers with ripe anthers pollen grains were found with three nuclei. This is a number considered as typical for the Gramineae family.

\section{DISCUSSION OF THE RESULTS}

On the basis of available for me literature concerning the development of the embryo sac in the Gramineae it was established that this species has not been studied yet. Having found that the embryo sac development in this species is of the Allium type, bisporial, the number of species in the Gramineae known to have such a development raises to three. This result is based on about 76 slides, containing stages from the megaspore mother cell to the diad.

There are three antipodals in this species, which is rather rare for the Gramineae, where larger numbers of antipodals prevail.

The parietal cell does not develop from the archesporial cell. Thus it directly becomes the megaspore mother cell.

\section{SUMMARY}

In Melica uniflora there exists a bisporial embryo sac of the Allium type. The embryo sac has. 3 antipodals. The polar nuclei during double fertilization have not fused yet in most of the plants

\section{ACKNOWLEDGEMENTS}

I wish to thank Dr M. Zenkteler for collecting the material and giving it to me. and B. Czosnowska. M. Sc. for technical help and for the preparation of the drawings. My thanks are due as well to Docent Dr T. Wojterski for his information concerning the distribution of the species studied. 
It was possible to perform this work entirely thanks to the financial help of the Botanical Committee of the Polish Academy of Sciences, for which the author expresses his most sincere gratitude.

\section{Department of General Botany}

A.M. University, Poznań,

al. Stalingradzka 14

Poland

(Entered: 14.I.1967.)

\section{REFERENCES}

Aly Mohamed H. and Frank Gould, 1966, Biosysthematic studies in the Boutelona curtipendula complex. V. Megasporogenesis and embryo sac development, Amer. J. Bot. 53. (2), $166-169$.

Battaglia E., 1958, L'abolizione del tipo embriologico Scilla e la creazione dei nuovi tipi Endymion et Allium, Caryologia. 11: 247-252.

Brown W. V. and W. H. P. Emery, 1958, Apomixis in the Gramineae: Panicoideae, (Amer.

J. Bot. 45, (4): 253-263.

Czosnowski E., 1965, The development of the ovule and embryo sac and the early development stages of the seed of Prunus cerasiefera Ehrl., Bull d.1. Soc. des amis de Sc. et des Lettr. de Poznań. Série D. livr. 6.

Darlington C. D., Wylie A. P., 1955, Chromosome atlas of flowering plants, London.

Fischer Alf, 1880, Zur Kenntniss der Embryosackenentwicklung einiger Angiospermen, Jenaische Zeitschrift für Naturwissesnschaftern Bd. 14, N. F.B.J. Jena pp. 90-132.

Johri B. M., 1963, A female gametophyte, [in Recent Advances in the Embryology of Angiosperms ed. by P. Maheshwari, Delhi].

Maheshwari S. C., 1955, The occurrence of bisporic embryo sac in Angiosperms - A critical review. Phytomorphology 5, (1): 67-99.

Meusel H., Jager E., Weinert E., 1965, Vergleichende Chorologie der Zentral europaischen Flora, Jena.

Schnarf K., 1926, Kleine Beiträge zur Entwicklungsgeschite der Angiospermen. VI. Über die Samenentwicklung einiger Gramineen, (Öster. Bot. Zeitschr. B. 75).

Stover E. L., 1937, The embryo sac of Eragrostis cilianensis (All.) Zinn. A new type of embryo sac and a summary of grass embryo sac investigations, (Ohio Jour. of Sc. 37).

Stephens E. L., 1909, The embryo sac and embryo of certain Penaeaceae, (Ann. Bot. 23. (91): 363-378).

Walczak A., 1965, Rozwój woreczka zalążkowego u Melica nutans L. (in Polish. First University degree thesis. Unpublished).

Willis I. C., 1951, A dictionary of the flowering plants and ferns, Sixth Edition Cambridge University Press.

\section{Megasporogeneza i rozwój woreczka zalqż̇kowego u Melica uniflora Retz}

\section{Streszczenie}

U Melica uniflora występuje bisporialny woreczek zalążkowy typu Allium. Archesporialna komórka nie oddziela komórki parietalnej, a staje się bezpośrednio macierzystą komórką megaspor. Po pierwszym podziale meiotycznym powstaje diada komórek. Dalszy rozwój zachodzi dwoma drogami; albo II podział meiotyczny zachodzi tylko w chalazalnej komórce, która się przez dalsze 
mitozy rozwija w 8-jądrowy woreczek zalążkowy, a górna mikropilarna komórka diady pozostaje 1-jądrowa i wkrótce degeneruje, albo II podział meiotyczny zachodzi w obu komórkach, powstają 2 komórki dwujądrowe, z których górna wkrótce degeneruje, a chalazalna rozwija się w 8-jądrowy woreczek zalążkowy. U Melica nutans, jak wykazał Fischer (1880) i sprawdziła A. Walczak (1965) woreczek rozwija się tylko tą drugą drogą.

Woreczek zalążkowy ma 3 antypody. Jądra polarne u większości roślin w okresie podwójnego zapłodnienia nie są jeszcze zlane. Bielmo jest typu jądrowego. W pylnikach łatwo było porachować ilość bilwalentów podczas I meiotycznej metafazy i ustalić, że $n=9$. Dojrzałe pyłki mają 3 jądra. 